\title{
Seaweed as novel food for prevention and therapy for life style related disease
}

\author{
Lindarsih Notowidjojo ${ }^{1}$
}

Received 15 February 2021

Accepted 17 February 2021

1. Department of Nutrition, Faculty of Medicine, Universitas Indonesia-Cipto Mangunkusumo Hospital, Jakarta

Link to DOI:

10.25220/WNJ.V05.i1.0001

Journal Website:

www.worldnutrijournal.org

\section{Introduction}

Seaweed has long been known and consumed as a functional food and folk medicine, especially in people who live in coastal areas. Research on seaweed has recently increased with the surge need for alternative sources of functional food to deal with health problems related to lifestyle, such as obesity, diabetes, hypertension and cardiovascular disease. Epidemiology studies have found that population consumed seaweed is on a regular basis have significantly less diet-related diseases. ${ }^{1,2}$ Even the largest population of old age is in Japan, which consumes the most seaweed in the world. ${ }^{1,3}$ In countries such as Japan, China, and Korea, approximately $66 \%$ of algae species have been used as a daily ingredient in their dishes for many years. ${ }^{4}$

Seaweed are autotrophic organism with unicellular morphology without roots, stems, leaves and flowers and is called a thallus, smooth, has many branches both long and short, the colors are usually red, brown or green. Seaweeds are commonly classified into three taxonomic groups Rhodophyta

\footnotetext{
Corresponding author:

Lindarsih Notowidjojo

Department of Nutrition, Faculty of Medicine,

Universitas Indonesia-Cipto Mangunkusumo Hospital,

Jl. Salemba Raya no.6, Central Jakarta, Indonesia

Email:lin_noto@yahoo.com
}

(red seaweed), Phaeophyta (brown seaweed) and Chlorophyta (green seaweed). The nutrient content in seaweed is very dependent on the type of marine biota, location and environment where the seaweed grows, so it is more varied than land plants. ${ }^{5,6}$ Seaweeds are abundant source of nutrient protein, dietary fiber, vitamin and minerals as a result of stressful situations on seaweed tissues, exposure to ultraviolet radiation, changes in temperature and salinity, or environmental pollutants. ${ }^{7}$ Seaweed is rich in: essential amino acids, dietary fiber, $\omega-3$ fatty acids, mineral and vitamins A, B, C, and E compared to the terrestrial plants and animal-based foods..$^{8,9}$

\section{Protein}

Seaweeds protein content depends on the type of seaweed and varies widely, protein contents was higher in red and green seaweeds $(10-47 \%$ of dry weight) than those found in brown seaweeds (5$24 \%$ dry weight $)^{9}$. Most seaweeds have a higher protein score than all plant-based proteins, with the exception of soy, which has a score of $1.0 .^{10,11}$ However, the high polyphenolic content of seaweeds can reduce the digestibility of seaweed proteins, giving a slightly lower score on the protein digestibility-corrected amino acid scale. ${ }^{12}$ Seaweed proteins are rich in glycine, arginine, alanine, and 
glutamic acid. Their limiting amino acids are lysine and cystine ${ }^{9,13}$

Bioactive proteins that can be extracted from seaweed are phycobiliproteins and lectins.

Some studies have shown that phycobiliproteins extracted from red algae (phycoerythrin) could be beneficial in the prevention or treatment of neurodegenerative diseases caused by oxidative stress (Alzheimer and Parkinson's) due to their antioxidant effects. ${ }^{9,14}$ Lectins can recognise and bind to specific carbohydrate structures and take part in many biological processes like intercellular communication and those isolated to date have highly novel amino acid sequences. ${ }^{15}$ The lectins found in Bryothamnion spp. (Rhodophyta) show an inhibitory effect on the growth of strains of Steptococcus spp.; therefore, they can be used as bactericidal compounds. ${ }^{9,16}$ Seaweed also contains peptides which have angiotensin converting enzyme inhibitor (ACE-I) activity. ${ }^{17,18}$

Protein digestibility is limited by the non- protein fraction, which accounts for $10-20 \%$ of the nitrogen content.The isolation of protein from algae is difficult due to viscous polysaccharides; the use of buffers and detergents for effective cell lysis and removal of polysaccharide was proposed. ${ }^{19}$

\section{Carbohydrate}

Seaweeds contains carbohydrate as polysaccharides that has been studied for their physiological and biological potential. Physiological potential of seaweed polysaccharides as sources of fiber. Insoluble fiber: cellulose is an indigestible, nonnutritive polysaccharide as structure of cell walls of seaweeds and constitutes from $2 \%$ to $10 \%$ of total polysaccharides. ${ }^{10}$ Soluble fiber is characterized by its ability to form viscous gels, in contact with water, in the intestinal tract. Soluble fiber is fermented in high proportion, and its main properties are related to the decrease of cholesterol and glucose in blood and the development of intestinal microbiota. ${ }^{9}$ Meanwhile, insoluble fiber or cellulose will decrease gastrointestinal transit time and prevent constipation. ${ }^{9,20}$

Seaweed cell walls are enriched with sulfated polysaccharides, that progressively investigated for their potential value in food and pharmaceutical applications. ${ }^{21}$ Sulfated polysaccharides in seaweed: laminarans and fucoidans in the Phaeophyta, carrageenans in the Rhodophyta, and ulvans in the Chlorophyta. ${ }^{22}$ One of the most vital properties linked with sulfated polysaccharides is their anticoagulant characteristics. Sulfated polysaccharide of green seaweeds from Ulva and Enteromorpha, are called ulvans, and their oligosaccharides, have demonstrated strong antitumor and immune-modulating activities, antihyperlipidemic activities and anticoagulant activities. $^{23}$

The main products of fiber fermentation are short chain fatty acids (SCFA), mainly acetic, propionic, and butyric, which lead to a drop in $\mathrm{pH}$ and even to the stimulation of the growth of certain microorganisms, modifying the bacterial metabolism in the colon, known as the prebiotic effect. ${ }^{6}$ In addition, SCFA may have a beneficial effect on cholesterol metabolism. ${ }^{9,24}$ In animal studies fed with red seaweed extract, the number of prebiotics bifidobacterium and lactobacillus increased. ${ }^{25} \mathrm{Al}-$ Sheraji, et al., concluded that prebiotics increase absorption of $\mathrm{Ca}$ and $\mathrm{Mg}$, can affect blood sugar levels and improve blood fat levels. ${ }^{26}$ In experiments with mice, those who were hypertensive and then given a diet containing $10 \%$ fiber powder from brown seaweed showed a significant reduction in blood pressure and a reduced incidence of stroke $(0$ versus $100 \%$ in the control group on day 30 of the experiment). In this study, it is suspected that alginic acid from seaweed fibers inhibits the absorption of $\mathrm{Na}$ in the digestive tract and has the effect of preventing an increase in blood pressure. ${ }^{27}$

\section{Fat}

The fat content of seaweed is low, about $1-5 \%$ of dry weight with a composition of polyunsaturated fatty acids such as omega 3 and omega 6. Omega 3 is mostly contained in green seaweed, while red and brown seaweed contains lots of fatty acids with 20 carbon atoms such as eicosapentanoic acid and arachidonic acid. ${ }^{5,28}$ The ratio between $n-6$ and $n-3$ fatty acid is considered an index for evaluating the nutritional value of a dietary lipid source..$^{29,30}$ An imbalance between $n-6$ and $n-3$ FAs in biological tissues is known to cause inflammatory processes in the body. ${ }^{30}$ since in western diets, the ratio has risen to around $15-20: 1,{ }^{31}$ this far beyond the ideal 
ratio, $(<5: 1) .{ }^{29}$ Since the $n-6 / n-3$ ratio of the seaweed was within the recommended range of $<5: 1$, they have the potential to enhance the nutritional quality of food products, e.g. by regulating low-density lipoprotein and cholesterol levels, and help to prevent inflammatory, cardiovascular diseases and nervous system disorders. ${ }^{10,29}$

Fatty acid composition also varies between different geographic regions; for example in warm water chlorophyta contain higher saturated fatty acid and oleic acid, but in cold water it will have higher polyunsaturated fatty acids levels. ${ }^{14,32,33}$ Polyunsaturated fatty acids (PUFA) are useful in regulating blood clotting, blood pressure, helping the function of the brain and nervous system. PUFA produce mediators called eicosanoids to regulate inflammatory reactions. ${ }^{5}$ Long chain PUFAs (LCPUFAs) play key roles in cellular and tissue metabolism, including the regulation of membrane fluidity, electron and oxygen transport, as well as thermal adaptation. ${ }^{14}$

\section{Vitamin and mineral}

Seaweeds contain both water- and fat-soluble vitamins. $^{6,28}$ Seaweed foods offer one of the few vegetarian alternatives for cobalamin (vitamin $\mathrm{B}_{12}$ ) in the diet. Ortiz in 2006 reported that 100 grams of seaweed can meet the daily needs of vitamins $\mathrm{A}, \mathrm{B}_{2}$, $\mathrm{B}_{12}$ and two-thirds of vitamin C. ${ }^{34}$ The content of red seaweed vitamins includes vitamin $B_{12}$, vitamins $C$, vitamin $\mathrm{E}$ and carotene. Vitamin $\mathrm{C}$ levels can reach 100-800 mg / $\mathrm{kg}$ in red seaweed. Vitamin E which acts as an antioxidant is also contained in seaweed. The availability of vitamin $\mathrm{E}$ in brown seaweed is higher than green and red seaweed. This is because brown seaweed contains $\alpha, \beta$, and $\gamma$-tocopherol, while green and red seaweed only contains $\alpha$ tocopherol. ${ }^{28,35}$. This vitamin is beneficial to health as an antioxidant, strengthens the immune system and is anti-aging. 5,35

Seaweed also contains minerals more than $36 \%$ dry weight with the content: calcium, magnesium and iodine as the main minerals. ${ }^{28}$ The natrium content in seaweed is generally low around $2-3 \%$, while the levels of kalium is around $5-6 \%$, so the natrium / kalium ratio of seaweed is around 0.3 . Composition of $\mathrm{Na}$ and $\mathrm{K}$ in seaweed is thought to be useful as an antihypertensive in mild hypertension. ${ }^{36}$ Seaweed also contains high levels of magnesium and calcium compared to land plants such as vegetables. ${ }^{20}$ Seaweed calcium can reach $7 \%$ of dry weight. ${ }^{28}$

\section{Limitation}

Seaweed bioactive consistency is a challenge for commercial application, since bioactive substance of seaweed is greatly vary and influenced by many factors, such as natural variability: type of species, time and location of harvest. ${ }^{32}$ Other limitation are accumulation of undesirable elements, heavy metals and other pollutants, such as: cadmium, mercury, plumbum and arsenic. $^{29}$ Cadmium level was relatively low in green seaweed compared with red and brown seaweed. The concentrations of mercury were relatively low in all species..$^{29,37}$ Lead was found to be low in red and brown seaweed compare with in green seaweed. ${ }^{29,38}$ Arsenic in biological matrices exists either in organic forms or as inorganic arsenic form, organo arsenic forms are considered to be non-toxic or of low toxicity. Total arsen were found in brown algae higher than other taxonomic groups with gradation as brown seaweed $>$ red seaweed $>$ green seaweed. ${ }^{37,38,38}$

\section{Conclusion}

Seaweed has long been consumed as a functional food and folk medicine for people who live in coastal areas. Seaweed contains elements of protein, carbohydrates including fiber, vitamins and minerals with a composition that can play a role in the prevention and therapy of diseases associated with modern life patterns. There are limitations of seaweed that can be applied commercially, namely the consistency of bioactive levels and the presence of unwanted substances such as heavy metals and other pollutants.

\section{Conflict of Interest}

Authors declared no conflict of interest regarding this article. 


\section{Open Access}

This article is distributed under the terms of the Creative Commons Attribution 4.0 International Licence

(http://creativecommons.org/licenses/by/4.0/), which permits unrestricted use, distribution, and reproduction in any medium, provided you give appropriate credit to the original author(s) and the source, provide a link to the Creative Commons license, and indicate if changes were made.

\section{References}

1. Nanri A., Mizoue T., Shimazu T., Ishihara J., Takachi R., Noda M., Iso H., Sasazuki S., Sawada N. \& Tsugane S.; for the Japan Public Health Center-Based Prospective Study G. 2017. Dietary patterns and allcause, cancer, and cardiovascular disease mortality in Japanese men and women: the Japan public health center-based prospective study. PLoS ONE 12: e0174848. DOI: 10.1371/journal.pone.0174848.

2. Iso H. 2011. Lifestyle and cardiovascular disease in Japan. Journal of Atherosclerosis and Thrombosis 18: 83-88. DOI: $10.5551 /$ jat.6866.

3. Kaneda T, Greenbaum C, and Patierno K. United Nations Population Division, 2020 World Population Data Sheet (Washington, DC: PopulationReference Bureau, 2019). https://population.un.org/wpp/Download/Standard/Pop ulation/

4. Rajapakse, N.; Kim, S.K. Nutritional and digestive health benefits of seaweed. In Advances in Food and Nutrition Research; Kim, S.K., Ed.; Academic Press: Waltham, MA, USA, 2011; pp. 17-28. ISBN 978-0-12387669-0.

5. Hamed I, Ozogul F, Ozogul Y, Regenstein JM. Marine Bioactive Compounds and Their Health Benefits. Food Science and Food Safety 2015;14:446-65.

6. Holdt S, Kraan, S. Bioactive compounds in seaweed: functional food applications and legislation. Applied Phycol. 2011;23:543-97.

7. Rosa GP, Tavares WR, Sousa PMC, Pagès AK, Seca AML, Pinto DCGA. Seaweed secondary metabolites with beneficial health effects: An overview of successes in in vivo studies and clinical trials. Mar. Drugs 2020, 18,8

8. Ruperez P. Mineral content of edible marine seaweeds. Food Chemistry 79 (2002) 23-26. Received 7 August 2001; received in revised form 18 February 2002; accepted 18 February 2002

9. Rocío Peñalver, José M. Lorenzo , Gaspar Ros, Ryszard Amarowicz, Mirian Pateiro and Gema Nieto. Review Seaweeds as a Functional Ingredient for a
Healthy Diet. Mar. Drugs 2020, 18, 301; doi: $10.3390 / \mathrm{md} 18060301$.

10. Shannon E \& Abu-Ghannam N. Seaweeds as nutraceuticals for health and nutrition, Phycologia 2019, 58:5, 563-577, DOI: 10.1080/00318884.2019.1640533

11. Murata M. \& Nakazoe J. 2001. Production and use of marine algae in Japan. Japan Agricultural Research Quarterly: JARQ 35: 281-290. DOI: 10.6090/jarq.35.281

12. Wong K.H. \& Cheung P.C.K. 2001. Nutritional evaluation of some subtropical red and green seaweeds Part II. In vitro protein digestibility and amino acid profiles of protein concentrates. Food Chemistry 72: 11-17. DOI: 10.1016/S0308-8146(00)00176-X.

13. Dhargalkar, V.K.; Verlecar, X.N. Southern Ocean seaweeds: A resource for exploration in food and drugs. Aquaculture 2009, 287, 229-242.

14. Bleakley, S.; Hayes, M. Algal Proteins: Extraction, Application, and Challenges Concerning Production. Foods 2017, 6, 33.

15. Admassu H, Zhao W, Yang R, Gasmalla MAA, Alsir E. Development Of Functional Foods: Sea Weeds (Algae) Untouched Potential And Alternative Resource - A Review. International Journal of Scientific \& Technology Research Vol. 4, issue 09, SEPTEMBER 2015.

16. Vasconcelos, M.A.; Arruda, F.V.S.; Carneiro, V.A.; Silva, H.C.; Nascimento, K.S.; Sampaio, A.H.; Cavada, B.; Teixeira, E.H.; Henriques, M.; Pereira, M.O. Effect of algae and plant lectins on planktonic growth and biofilm formation in clinically relevant bacteria and yeasts. Biomed Res. Int. 2014.

17. Cha S, Lee KW., Jeon, YJ. Screening of Extracts from Red Algae in Jeju for Potentials Marine Angiotensin - I Converting Enzyme (ACE) Inhibitory Activity. Algae 2006;21:343-8.

18. Suetsuna K, Nakano T. Identification of an antihypertensive peptide from peptic digest of wakame (Undaria pinnatifida). J Nutr Biochem 2000;11:450-4.

19. Chojnacka., K.; Saeid., A.; Witkowska., Z.; Tuhy., Ł., Biologically Active Compounds in Seaweed Extracts the Prospects for the Application. The Open Conference Proceedings Journal, 2012, 3, (Suppl 1-M4) 20-28.

20. Cardoso SM, Pereira OR, Seca AM, Pinto DC, Silva AM. Seaweeds as Preventive Agents for Cardiovascular Diseases: From Nutrients to Functional Foods. Mar. Drugs 2015;13(11):6838-65.

Doi: $10.3390 / \mathrm{md} 13116838$

21. Muthukumar, J., Chidambaram, R. \& Sukumaran, S. Sulfated polysaccharides and its commercial applications in food industries - A review. J Food Sci Technol(2020). https://doi.org/10.1007/s13197-02004837-0.

22. Wijesekara, I.; Pangestuti, R.; Kim, S.-K. Biological activities and potential health benefits of sulfated polysaccharides derived from marine algae. Carbohydr. Polym. 2011, 84, 14-21. 
23. Wang L, Wang $\mathrm{X}, \mathrm{Wu} \mathrm{H}$, Liu R. Overview on Biological Activities and Molecular Characteristics of Sulfated Polysaccharides from Marine Green Algae in Recent Years. Mar Drugs. 2014 Sep; 12(9): 4984-5020. Published online $2014 \quad$ Sep 25. doi: 10.3390/md12094984

24. Devillé, C.; Gharbi, M.; Dandrifosse, G.; Peulen, O. Study on the effects of laminarin, a polysaccharide from seaweed, on gut characteristics. J. Sci. Food Agric. 2007, 87, 1717-1725.

25. Kuda T, Yano T, Matsuda N, Nishizawa M. Inhibitory effects of laminaran and low molecular alginate against the putrefactive compounds produced by intestinal microflora in vitro and in rats. Food Chem 2005; 91:745-49.

26. Al-Sheraji S, Ismail A, Manap MZ, Mustafa S, Yusof RM, Hassan FA. Prebiotics as functional foods: A review. J Funct Foods 2013;5:1542-53.

27. Yamori Y, Nara Y, Tsubouchi T, Sogawa Y, Ikeda K, Horie R. Dietary prevention of stroke and its mechanisms in stroke-prone spontaneously hypertensive rats-preventive effect of dietary fibre and palmitoleic acid. J Hypertens Suppl. 1986;4:S449-52.

28. Burtin P. Nutritional value of seaweed. Electron J Environ Agric Food Chem 2003;2

29. Biancarosa I, Belghit I, Bruckner CG, et al. Chemical characterization of 21 species of marine macroalgae common in Norwegian waters: benefits of and limitations to their potential use in food and feed. $J$ Sci Food Agric. 2018;98(5):2035-2042. doi:10.1002/jsfa.8798.

30. Calder PC, n-3 Polyunsaturated fatty acids, inflammation, and inflammatory diseases. Am J Clin Nutr 83:S1505-1519S (2006).

31. Simopoulos AP, Omega-6/omega-3 essential fatty acids: biological effects. World Rev Nutr Diet 99:1-16 (2009).

32. Stengel, D. B.; Connan, S.; Popper, Z. A., Algal chemodiversity and bioactivity: sources of natural variability and implications for commercial application. Biotechnology advances 2011, 29, 483-501.

33. Kumari P, Kumar M, Gupta V, Reddy CRK, Jha B. Tropical marine macroalgae as potential sources of nutritionally important PUFAs. Food Chem 2009;120:749-57.

34. Ortiz J, Romero N, Robert P, Araya J, LopezHernandez J, Bozzo C, dkk. Dietary fiber, amino acid, fatty acid and tocopherol contents of the edible seaweeds Ulv, a lactuca and Durvillaea antarctica. Food Chem. 2006;99:98-104. DOI: 10.1016/j.foodchem.2005.07.027

35. Kumar K, Ganesan K., Subba Rao, PV. Antioxidant potential of solvent extracts of Kappaphycus alvarezii (Doty). Doty an edible seaweed. Food Chemistry, 2008;107:289-95.

36. Krotkiewski M, Aurell M, Holm G, Grimby G, Szczepanik J. Effects of a sodium-potassium ionexchanging seaweed preparation in mild hypertension. Am J Hypertens. 1991;4:483-88.

37. Almela C, Algora S, Benito V, Clemente MJ, Devesa V, Súñer MA et al., Heavy metal, total arsenic, and inorganic arsenic contents of algae food products. J Agric Food Chem 50:918-923 (2002).

38. Mæhre HK, Malde MK, Eilertsen K-E and Elvevoll EO, Characterization of protein, lipid and mineral contents in common Norwegian seaweeds and evaluation of their potential as food and feed. J Sci Food. Agric 94:32813290 (2014).

39. Rose M, Lewis J, Langford N, Baxter M, Origgi S, Barber $\mathrm{M}$ et al., Arsenic in seaweed - forms, concentration and dietary exposure. Food Chem Toxicol 45:1263-1267 (2007). 